ENTREPRENEURSHIP AND SUSTAINABILITY ISSUES

ISSN 2345-0282 (online) http://jssidoi.org/jesi/

2020 Volume 7 Number 3 (March)

http://doi.org/10.9770/jesi.2020.7.3(73)

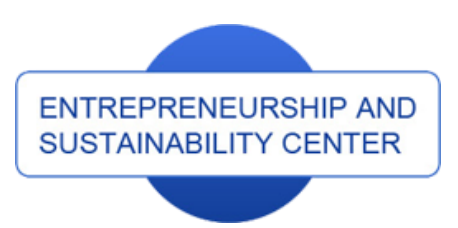

Publisher

http://jssidoi.org/esc/home

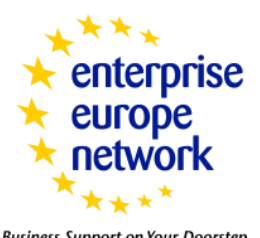

Business Support on Your Doorstep

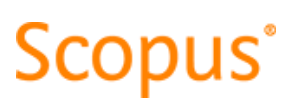

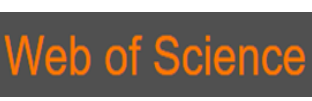

Clarivate

Analytics

\title{
RESEARCH OF MOTIVATION OF EMPLOYEES IN THE IT SECTOR IN BULGARIA *
}

\author{
Kiril Anguelov ${ }^{1}$, Tsvetana Stoyanova ${ }^{2}$, Rima Tamošiūniené ${ }^{3}$ \\ ${ }^{I}$ Technical university of Sofia, French Faculty of Electrical Engineering, Kliment Ohridsky blv St 8, Sofia, Bulgaria \\ ${ }^{2}$ University of National and World Economy, Faculty of Management and Administration, Studentski grad, Sofia, Bulgaria \\ ${ }^{3}$ Vilnius Gediminas Technical University, Business Management Faculty, Sauletekio ave. 11, Vilnius, Lithuania \\ E-mails:1ag@tu-sofia.bg ;² tsvetana_stoyanova@unwe.bg ; ${ }^{3}$ rima.tamosiuniene@vgtu.lt
}

Received 18 September 2019; accepted 25 January 2020; published 30 March 2020

\begin{abstract}
The motivation of professionals is not based solely on good monetary remuneration. Nowadays, every experienced IT professional is interested first and foremost in a healthy work environment in a company and then on the pay level. The employer's assessment takes into account the level of stress, work-life balance, career development prerequisites, as well as the offered social benefits supplementary health insurance, sports cards, food vouchers, drinks and fruit at work, events with colleagues outside the office, places for creative relaxation at work. Anything that helps the creative workflow because IT professionals, are creators in the field who work and need special conditions to grow their potential and deliver good results. The article explores and analyzes the motivation factors leading to the employees' commitment of the IT companies in Bulgaria. Basic theoretical points of view are presented and the work of leading researchers in this field is being commented. A methodology has been developed and the summarized results are presented, on the two hypotheses that the authors set, namely: There is a link between Employee Compensation, working conditions, personal development opportunities and the psychological climate, and employee engagement and that Employee Compensation has exhausted the possibilities to be the only factor to guarantee the commitment of the employees in the IT industry. The results show that companies can not ignore any of the identified key motivational factors without losing employees and/or productivity/efficiency.
\end{abstract}

Keywords: stress; employees; job satisfaction; employee engagement; talent management; personnel; working conditions

Reference to this paper should be made as follows: Anguelov, K., Stoyanova, T., Tamošiūnienè, R. 2020. Research of motivation of employees in the IT sector in Bulgaria. Entrepreneurship and Sustainability Issues, Entrepreneurship and Sustainability Issues 7(3), 25562567. http://doi.org/10.9770/jesi.2020.7.3(73)

JEL Classifications: M15, J24, J28

\footnotetext{
* The authors would like to thank the Research and Development Sector at the Technical University of Sofia, Bulgaria, for the financial support.
} 


\section{ENTREPRENEURSHIP AND SUSTAINABILITY ISSUES}

ISSN 2345-0282 (online) http://jssidoi.org/jesi/

2020 Volume 7 Number 3 (March)

http://doi.org/10.9770/jesi.2020.7.3(73)

\section{Introduction}

Currently, company management theory focuses on various interrelated approaches to achieve and maintain their competitiveness, namely:

- effective marketing guaranteeing successful interaction with the market and sales at good prices and in the required quantities;

- an innovative system capable of responding to all the emerging needs;

- a highly productive production and logistics system for goods/services aimed at minimizing cost/expenses as much as possible;

- financial and resource security of the activity of the company;

- highly-effective and efficient human capital management of the company.

Human capital is closely linked to the achievement of all the goals that companies put for themselves. In this regard, the major efforts of any company wishing to achieve economic prosperity are related to the highly effective and efficient management of human capital, which includes:

- high quality selection of employees;

- system for training, qualification and re-qualification of employees;

- ensuring the working conditions necessary for performing the working process;

- motivating employees and ensuring their loyalty to the company.

Of course, a successful motivation system requires both an effective training qualification and re-qualification system for the employees, as well as ensuring the working conditions necessary for performing the working process; In addition, however, companies must provide motivational payroll systems and various other measures that bring the employee to the satisfaction of his work. It is necessary for the person to feel valued at each of the hierarchical levels in the company, at each position occupied in it. The paths for successful motivation of employees depend on a number of factors that have different influences depending on the type of company, the industry, the general economic situation in the region, cultural characteristics, etc. Effective motivation is therefore related to the study of the laws, principles and rules that differentiate rational human behavior and influence the full use of its labor potential. In this regard, it is necessary to emphasize that the company employee is characterized by individual behavioral traits, qualifications, knowledge, skills and cultural features. This is also the reason why the successful forms of motivation in one company applied in another do not lead to the desired degree of commitment of the employees to the fulfillment of its goals. The low degree of commitment, despite the motivational efforts made, does not allow the companies to take advantage of a decisive competitive advantage in three important directions: higher performance; higher consciousness and quality of work and lower turnover. The concept of employee engagement is built on the above considerations. In the context of ever-increasing competition from companies, on the same terms, to achieve resources and opportunities to create goods and services, successful motivation leading to employees' engagement is one of the strongest opportunities to realize a competitive advantage. Undoubtedly this fact is connected with the introduction of the problems related to the link between motivation and engagement of the employees both in the scientific researches and in business. Under these conditions, the need to carry out empirical research to establish employee engagement in specific business conditions, and in this connection to provide concrete solutions for specific industries and / or regions becomes, grows by the day. These are the preconditions, under which the object, subject, and purpose of this article are defined.

The main objective of the survey is to establish the level of commitment of the employees in the IT sector in the region of Sofia, following the example of leading IT companies. The IT sector is among the fastest-growing in Bulgaria with high value added. The consequence of this is the size of the investments made, as well as the working conditions offered. Those employed in this branch are mostly young specialists who have an interest and knowledge in the field of technology and the market of information resources. Because of the offer of quality skills and knowledge by such specialists, to keep them requires extraordinary efforts and an individual approach. 


\section{ENTREPRENEURSHIP AND SUSTAINABILITY ISSUES}

ISSN 2345-0282 (online) http://jssidoi.org/jesi/

2020 Volume 7 Number 3 (March)

http://doi.org/10.9770/jesi.2020.7.3(73)

Although the development of the sector is at national level, it is significantly stronger in the capital Sofia, where the main investments are concentrated. In Sofia is also the biggest shortage of IT specialists. This poses with much higher strength the question of the level of remuneration, motivation and commitment than in other regions of Bulgaria. The general research argument is that Employee Compensation in this sector has exhausted its role as a sole motivator, and other motivators that can be identified in the survey should be used to ensure employee engagement with company goals.

\section{Literature Review}

\subsection{Evolution of the theoretical postulates about employee engagement}

The concept of employee engagement is relatively new in human resource management and has only emerged in literature since the last decade of the last century (Bagyo, 2014). Until now, there is no single and general definition of the term employee engagement. Although different researchers define engagement differently, there are some common elements inherent in each of them. These elements are employees' satisfaction with their work and pride of their employer, the extent to which people have fun and believe in what they are working on, and the understanding that their employer appreciates the contribution of each one of them (e.g. Schouten, 2019; Bernardi, 2019; Thandabhani, 2020). Thus, Robinson, Perryman and Hayday (2002) defines engagement as "a positive attitude of employees towards the organization and its values. According to him, the employee is familiar with the business context and works with his colleagues to improve his performance in order to prosper the business. For its part, the organization works with the idea to develop and breed engagement, which predetermines the two-way relationship between employee and employer".

Michael Bradley Shuck and Karen K. Wollard (Schuck, \& Wollard, 2013) claim that engagement is the employees' willingness and capability to help for the success of the company by making constant efforts to do so. In their opinion, engagement is influenced by many factors both emotional and rational related to work and experience. Gallup defines employee engagement as commitment and enthusiasm for work, as well as positive emotional attachment and dedication by the employees. In addition to that, Fernandez (Tripathi and Sharma, 2016) describes the difference between the well-known thesis in the management of job satisfaction and engagement, claiming that employee satisfaction is not the same concept as engagement, as managers can not rely on employees' satisfaction to keep the most capable of them. In this case, employee engagement becomes an essential criterion. According to the Corporate Leadership Council, engagement is the extent to which employees are devoted to something or someone in their organization, how hard they work, and how long they stay as a result of their devotion (Vance, 2006).

For The Insights Group Ltd employees' commitment is their emotional commitment to their organization and the actions they take to achieve overall success. Such employees demonstrate concern, enthusiasm and focus on results (Insights Group, 2014).

A summary of all the above, we can do with the following Figure 1: 
ENTREPRENEURSHIP AND SUSTAINABILITY ISSUES

ISSN 2345-0282 (online) http://jssidoi.org/jesi/

2020 Volume 7 Number 3 (March)

http://doi.org/10.9770/jesi.2020.7.3(73)

Conceptual framework of emloyees' engagement

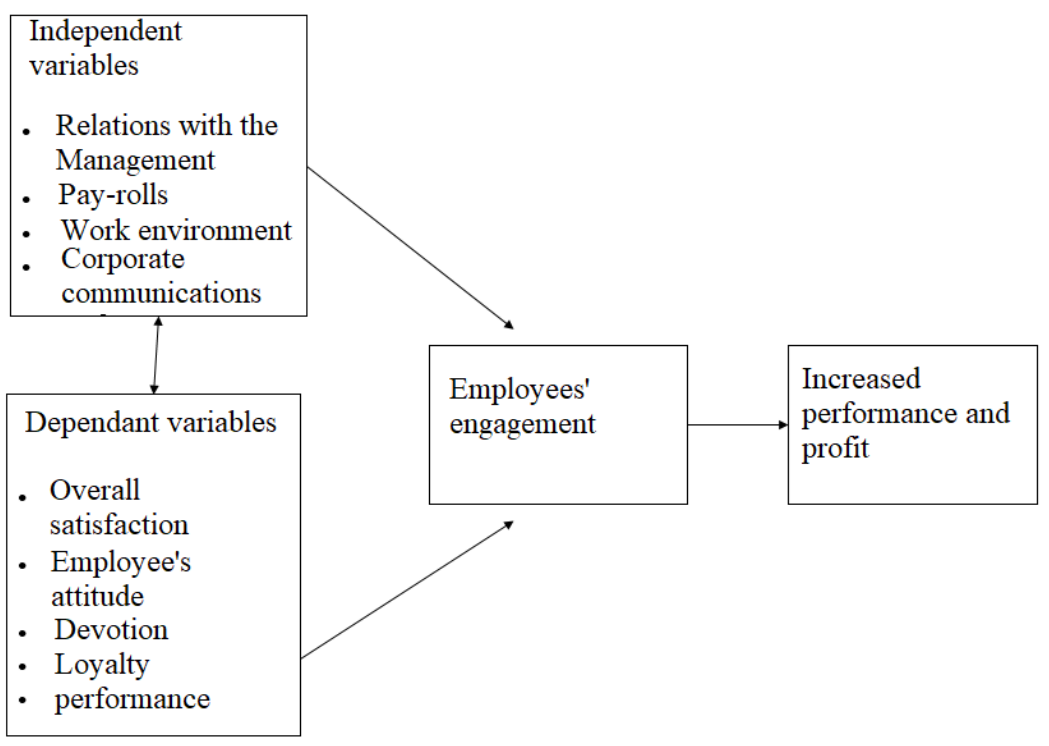

Figure 1. A conceptual framework of employee engagement

Source: https://www.shrm.org/hr-today/trends-and-forecasting/special-reports-and-expert-views/Documents/Employee-EngagementCommitment.pdf p.16; the figure was supplemented by the authors

The figure shows that engagement is related to the emotional characteristics of the relationship between the company and the employees and directly affects their business results (Audit Advice Associates, 2015). Engaged employees make real efforts and enthusiasm to achieve their personal and general business goals, are concerned about the development and wellbeing of the company. At the same time, they tend to a lesser extent to changing jobs and seeking their individual development in another organization. On the contrary, they recognize the business objectives, the vision and the mission of the company and find the place of their individual goals in them. As a result, they are much more productive, more loyal and would always recommend their company as a good place to work.

\subsection{State of the IT Sector in Bulgaria and more particularly in Sofia}

The IT sector is developing extremely dynamically in Bulgaria. Although the leaders in the European Union remain (European Communities, EVROSTAT, 2019). Britain, Germany, France, followed closely by Italy and Spain, this sector has been growing more and more successfully in Bulgaria. According to the Bulgarian Association of Software Companies (BASCOM), the annual revenue from 2012 to 2018 has risen from 619 to 1502 million euros, with growth of between 15 and 29 percent in each year (BASCOM, 2019a). In this respect, the share of GDP in the sector is growing from 1.5\% to $2.8 \%$ with a forecast in 2020 to reach 3\% of the GDP if Bulgaria. Correspondingly, the industry covers more than 30000 employees, with statistics on employee growth increasing by between $10 \%$ and $22 \%$ on an annual basis. For the year 2018, 2855 new IT specialists were employed. This is more than the average per capita of IT specialists for the EU. One of the main obstacles for the growth, which most of the IT companies highlight, is the scarcity of enough IT specialists they can hire.

Under these circumstances, it is interesting to track the Employee Compensation, which average is 3 times higher than the country average; and the grow for 2018 is 5\%. In this respect, it is interesting to trace a comparison between the Employee Compensation in Bulgaria and the EU leaders in the sector - the United Kingdom and Germany. At an average annual employee of an IT company operating in Bulgaria, it is 45962 BGN, bringing Purchasing Power Parity (PPP) conversion factor 49066 GBP and 50838EUR. In comparison, the average Employee Compensation for software engineer in the UK is $34653 \mathrm{GBP}$, and in Germany 50556 EUR 


\section{ENTREPRENEURSHIP AND SUSTAINABILITY ISSUES}

ISSN 2345-0282 (online) http://jssidoi.org/jesi/

2020 Volume 7 Number 3 (March)

http://doi.org/10.9770/jesi.2020.7.3(73)

(BASCOM, 2019a, 2019b). The data provided is sufficiently indicative, and can draw the following main conclusions:

- despite the constant growth in the IT sector in Bulgaria there is a significant shortage of qualified IT specialists;

- the main business benefits of the sector are not rooted in low labor remuneration, which goes beyond the leading countries of the sector in the European Union;

- Bulgaria's main competitive advantages are both the good information connectivity and the traditions that exist, the good common conditions for the of IT business performance and, last but not least, the high quality (as performance and meeting the deadlines) of the IT companies operating in Bulgaria;

- Employee Compensation has exhausted its role as the only motivator. Its promotion of 5\% or more per year is perceived as normal and can not serve as employee engagement with companies. What is more, in the conditions of a lack of skillful qualified specialists, it is extremely unrealistic to expect not engaged personnel to be detained in the companies - there will be someone to offer a higher salary;

- the very good reliance on the necessary motivators and their application, while guaranteeing Employee Compensation within the framework offered by competing companies, can provide the necessary commitment and dedication to the work of IT specialists.

Here it is necessary to point out another specificity of the IT sector, apart from the above mentioned high qualification of the personnel and respectively their deficiency. This peculiarity is related to the IT business processes themselves. Employees work in teams, but very often an employee is responsible completing a certain piece of the software. His sudden leave, as a result of accepting a better, according to him, offer from a competing firm, may seriously delay the implementation of a software project (finding a replacement, the time for his deputy to get acquainted with what has been done so far, the time for achieving effective teamwork). This is another reason why software companies in Bulgaria have reason to apply the principles of employee engagement to their business.

The stated wage values are average for the country. The main part of this business is concentrated in Sofia. Despite there, the IT sector is develops in several large cities (Plovdiv, Varna, Veliko Tarnovo, Rousse, etc.) but with a business scope and an Employee Compensation level unmatched by that in Sofia. This is one of the reasons for selecting the subject of the study.

On the other hand, in Sofia IT companies can be classified according to several criteria:

- according to the major investment: Bulgarian companies and companies with foreign capital representations in Bulgaria;

- according to the final products: companies developing their own products or those providing services to other companies (creation of custom software, maintenance of software systems and / or customer communications, etc.);

- according to the size: small companies with several IT specialists who, if they have a good business strategy, can grow into big companies leading in the sector.

There are small and leading companies from both the first and the second classification attributes. Typical for small companies is their higher flexibility towards the environment, but also the smaller resources available and dedicated departments for the management and development of human capital. In this article, it is chosen to establish the state of engagement among the leading companies in the IT sector in Sofia. Small companies, given that they are successfully developing in the current competitive environment, obviously also have a successful practice to ensure employee engagement. They will be analyzed in the next study of the authors.

This study is also topical in view of the expectation of more than $80 \%$ of the companies represented at BASCOM to increase by $10 \%, 25 \%$ or directly $50 \%$ of the employees (BASCOM, 2019a). 


\section{ENTREPRENEURSHIP AND SUSTAINABILITY ISSUES}

ISSN 2345-0282 (online) http://jssidoi.org/jesi/

2020 Volume 7 Number 3 (March)

http://doi.org/10.9770/jesi.2020.7.3(73)

\section{Methodology of the study}

The research is based on the collection and analysis of quantitative and qualitative data obtained from the interviews of employees in IT companies in Sofia. The questionnaire was sent (employees were invited to participate in survey) to 150 employees in Bulgarian and foreign IT companies operating in the capital. Anonymity when completing the questionnaire is guaranteed in order to obtain honest answers. The questionnaire is designed to identify:

1. Employee's level of engagement;

2. The effectiveness of the motivation factors leading to this engagement;

3. Potential opportunities to increase engagement.

In this connection, the following two research hypotheses are put forward:

H1: There is a link between Employee Compensation, working conditions, personal development opportunities and psychological climate, and employee engagement.

There is a link between Employee Compensation, working conditions, personal development opportunities and the psychological climate, and employee engagement

H2: Employee Compensation has exhausted the ability to be the only factor to ensure employee engagement in the IT industry.

The latter hypothesis is provoked by the previous research findings, where the strong need of Training of employees in High-technological Enterprises, is identified as a motivation factor (Mihova, 2018).

Taking into account the specificity of the IT industry on one hand and the research objectives on the other, the developed questionnaire which further develops the questions by Kenexa, an IBM company (Kenexa, 2013). The Kenaxa questionnaire was also used in other scholars' researches (Wiley, 2010). The following 4 questions are basic in the Kenexa questionnaire, and they are also used in this study:

1. I am proud to work for this company.

2. Overall, I am extremely satisfied with this company as a place to work.

3. I would gladly recommend this company as a great place to work.

4. I rarely think about looking for a new job with another company.

The questionnaire has been made in three parts:

1. Respondent statistical information: Sex; Age; How long do you work for your company?; How many years have you worked in the Information and Communication Industry? Is your company a Bulgarian or a foreign one? As discussed above, this study focuses on engagement with leading companies, so respondents are not being asked about the size of the organization they work for.

2. Closed questions with a predefined, most often a seven-tiered answer scale:

2.1. I'm proud to work in this Company;

2.2. My efforts in the company have been well appreciated through Employee Compensation

2.3. The company has provided good working conditions, which gives me the opportunity to apply creativity to my work;

2.4. The good relationships in the company make me feel part of the company and perceive its company culture as my own.

2.5. I feel motivated to the maximum in the team I work in

2.6. I think there is an opportunity to improve my achievements if I change the team I work with

2.7. I feel the company's commitment to my personal and professional development through the trainings and opportunities for new positions that I am offered;

2.8. I feel that the best way to continue my professional development is in my current company;

2.9. The company has achieved a good work/life balance that motivates me to contribute the maximum of my abilities into my work.

2.10. Workplace security (from dismissal/redundancy) is very important to me and makes me engage with the company. 


\section{ENTREPRENEURSHIP AND SUSTAINABILITY ISSUES}

ISSN 2345-0282 (online) http://jssidoi.org/jesi/

2020 Volume 7 Number 3 (March)

http://doi.org/10.9770/jesi.2020.7.3(73)

2.11. Please rank by importance the factors that are important to you: Employee Compensation, working conditions, relationships and communication within the company; training and opportunity for new positions; work/life balance; Workplace security.

2.12. Would I work harder for the company if Employee Compensation rises, but the other factors get worse?

2.13. Overall, I am extremely satisfied with this company as a place to work.

2.14. I would gladly recommend this company as a great place to work.

2.15. I rarely think about looking for a new job with another company.

2.16. I feel connected to the company because of the overall capabilities that it provides me as a professional and person.

3. Open questions to identify missing factors of influence

3.1. What motivates me most to work in my company is ...

3.2. The hardest demotivation for me in my work can be...

3.3. What do you think would engage you with the company and is currently missing ...

\section{Summarized survey results and comments}

\subsection{Statistical data and distribution of respondents}

The distribution of respondents by: sex; age; period of work in the company and in the IT sector, and the type of company with regard to local/foreign origin is summarized in Table 1.

The balance between men and women is very good among the respondents (which is a common feature for the $\mathrm{T}$ sector in Bulgaria) - respectively 55\% and $45 \%$. The main respondents who have filled in the questionnaire fall into the groups from the age of 22 to 45 . This is also the actual situation regarding the age structure of the employees in the IT sector in Bulgaria. Interesting is the grouping of employees according to work experience in the company and years in the IT sector.

Grouping according to work experience in the IT sector is done for the following reasons: trainees in the sector (up to 1 year) - 17\%; entering the sector (1 to 3 years) - 45\%; settled in the sector (3 to 7 years) - 27\%; Developing in the sector (7 to 12 years) - 9\%; IT industry experts (over 12 years) - $2 \%$. For each of these groups, the average level of professional rankings, job positions, requirements towards the IT company are different. It is interesting to follow the overlapping with the work experience in the respondent's current company: up to 1 year (34\%), from 1 to 5 years (59\%), from 5 to 12 years (6\%) and over 12 years (1\%). Almost no employees have spent their entire work experience in only one IT company.

On the other hand, it is a bad attestation for the involvement of IT specialists when a multiple change of employers has taken place. Employer change at the beginning of the career may be due to objective reasons not related to the motivation factors of the company: the beginning of an IT career is very often related to the search for technology and business culture with which IT professionals can achieve the highest performance. The majority of the respondents (78\%) are from foreign companies operating in Bulgaria and more specifically in Sofia; only $22 \%$ of respondents work in companies with Bulgarian capital. This is typical for the large IT companies in Bulgaria. The comparison can show the impact of the imported by the parent company culture in Bulgaria. 


\section{ENTREPRENEURSHIP AND SUSTAINABILITY ISSUES}

ISSN 2345-0282 (online) http://jssidoi.org/jesi/

2020 Volume 7 Number 3 (March)

http://doi.org/10.9770/jesi.2020.7.3(73)

Table 1. Statistical data and distribution of respondents

\begin{tabular}{|c|c|c|c|c|c|c|}
\hline Criteria & \multicolumn{6}{|c|}{ Allocation } \\
\hline Gender & \multicolumn{3}{|c|}{ Male } & \multicolumn{3}{|c|}{ Female } \\
\hline Age & Up to 23 & $23-30$ & $30-35$ & $35-40$ & $40-45$ & Over 45 year \\
\hline \multirow{2}{*}{$\begin{array}{l}\text { Work } \\
\text { experience in } \\
\text { the company }\end{array}$} & Up to 1 year & \multicolumn{2}{|c|}{ From 1 to 5 years } & \multicolumn{2}{|c|}{ From 5 to 12 years } & Over 12 years \\
\hline & $34 \%$ & \multicolumn{2}{|c|}{$59 \%$} & \multicolumn{2}{|c|}{$6 \%$} & $1 \%$ \\
\hline $\begin{array}{l}\text { Work } \\
\text { experience in } \\
\text { the IT sector }\end{array}$ & $17 \%$ & $45 \%$ & $29 \%$ & & & $2 \%$ \\
\hline \multirow{2}{*}{$\begin{array}{l}\text { Type of } \\
\text { company }\end{array}$} & \multicolumn{3}{|c|}{ Bulgarian } & \multicolumn{3}{|c|}{ Foreign } \\
\hline & \multicolumn{3}{|c|}{$22 \%$} & \multicolumn{3}{|c|}{$78 \%$} \\
\hline
\end{tabular}

\subsection{Closed questions with predefined answers}

This is the essence of the survey, with the statistically processed average values given in Table 2 . The majority of questions have a predefined scale of 1 to 7 , where 1 is the lowest possible and 7 is the highest. The results of questions that have no score-defining value, but indicate the respondents' opinion on the ranking of motivational factors are given in Table 3.

The first main conclusion is the high degree of commitment of the respondents to the companies they work in manifested through their pride in working with the company (score 6.4), with extremely satisfied with this company (score 6.1), with that they will recommend this company as a great place to work (score 6.2) and that they rarely think about looking for a new job with another company (6.5).

These results are complemented by the satisfaction by the Employee Compensation (which can never be fully met and, respectively, lower than the previous questions), a score of 5.9. Obviously, the respondents are satisfied with the working conditions that allow them to work in a creative environment (score 6.4) and the good micro climate they are very keen on (6.3). A fairly large proportion of them feel good about the team they work in (5.9). The latter two questions are largely inversely proportional to the next one - the ability to work better in another team (score 5.1). What is typical for this question is that high values were mostly given by employees with low work experience or those who have recently come to the company.

As in other studies (Mihova, Anguelov and Ferdov, 2018), the high importance of the training and qualification of the staff is demonstrated as an opportunity to increase their engagement - a score of 6.7. This motivation factor was presented relatively equally among all groups of respondents in the extract. The next question is controlling the previous one and, accordingly, has a similar value (score 6.5), given that the respondents feel the company's commitment to professional and personal development is perfectly normal to want to continue their professional development there.

Respondents are particularly sensitive to preserving work/life balance (score 6.6), indicating that this indicator should also be in the companies focus. In relation to that, it is a common answer of the hypothetical opportunity for the employee to sacrifice some of his privileges or conditions of work with the compensation of a higher salary (score 4.3). Higher values for this question are generally provided by younger and less experienced employees. With the older and more experienced employees in the companies and/or the IT industry, this option is not a leading one. 


\section{ENTREPRENEURSHIP AND SUSTAINABILITY ISSUES}

ISSN 2345-0282 (online) http://jssidoi.org/jesi/

2020 Volume 7 Number 3 (March)

http://doi.org/10.9770/jesi.2020.7.3(73)

Relatively low is the assessment of workplace security (score 3.2). This is due not to the underestimation of the permanent workplace and to the security related to it, but due to the shortage of IT specialists and respectively the perceived feeling that a job can be quickly found in a company of the similar activity under the same or better conditions than before. The feeling is also associated with the assumption that companies are struggling to hire and retain an IT specialist rather than vice versa.

As a result of everything discussed above, respondents feel connected to the company because of the wide range of opportunities they provide as professionals and individuals (score 6.1). In this relation, interesting is the degree of importance of the factors that motivate the respondents (Table 2).

Table 2. Closed questions with predefined answers

\begin{tabular}{|l|c|}
\hline \multicolumn{1}{|c|}{ Question } & $\begin{array}{c}\text { Average arithmetic value } \\
1 \mathrm{~min}-7 \mathrm{max}\end{array}$ \\
\hline I am proud to work for this company & 6.4 \\
\hline My efforts in the company have been well appreciated through Employee Compensation & 5.9 \\
\hline $\begin{array}{l}\text { The company has provided good working conditions, which gives me the opportunity to apply creativity to } \\
\text { my work; }\end{array}$ & 6.4 \\
\hline The good relationships in the company make me feel part of it and perceive its company culture as my own. & 6.3 \\
\hline I feel motivated to the maximum in the team I work in & 5.9 \\
\hline I think there is an opportunity to improve my achievements if I change the team I work with & 6.1 \\
\hline $\begin{array}{l}\text { I feel the company's commitment to my personal and professional development through the trainings and } \\
\text { opportunities for new positions that I am offered; }\end{array}$ & 6.7 \\
\hline I feel that the best way to continue my professional development is in my current company; & 6.6 \\
\hline $\begin{array}{l}\text { The company has achieved a good work/life balance that motivates me to contribute the maximum of my } \\
\text { abilities into my work. }\end{array}$ & 3.2 \\
\hline $\begin{array}{l}\text { Workplace security (from dismissal/redundancy) is very important to me and makes me engage with the } \\
\text { company. }\end{array}$ & 4.3 \\
\hline Would I work harder for the company if Employee Compensation rises, but the other factors get worse. & 6.1 \\
\hline Overall, I am extremely satisfied with this company as a place to work. & 6.2 \\
\hline I would gladly recommend this company as a great place to work. & 6.5 \\
\hline I rarely think about looking for a new job with another company. & 6.1 \\
\hline $\begin{array}{l}\text { I feel connected to the company because of the overall capabilities that it provides me as a professional and } \\
\text { person. }\end{array}$ & \\
\hline
\end{tabular}

The following main conclusions stand out:

1. Undoubtedly the most important is Employee Compensation. 54\% of respondents point to it on first place, and $19 \%$ on second.

2. The lowest impact on respondents is job security, the reason for which was already commented. Workplace security is taken for granted in this sector of the economy.

3. Significant influence of motivation is offered by the opportunities of development through "trainings and opportunity of new positions". This applies both to employees with an IT service experience of up to 5 years (the most prominent) and to more experienced employees. A total of 33\% puts it at the forefront of importance. The remainder of the respondents determined it by a level of importance comparable to "working conditions", "relationships and communication within the company" and "work/life balance".

4. The other 3 factors collect similar scores. This confirms the conclusions from the questions discussed above. Companies not only can't afford to bet on just one factor and to neglect the others, but they cannot ignore any of the significant ones without at the same time reducing employee engagement.

5. The "work/life balance" factor has the lowest impact on employees who have been 5 years or less in the IT sector. Its influence significantly grows among the IT specialists with a significant experience.

With the comments questions, both research hypotheses are unequivocally confirmed. 
ENTREPRENEURSHIP AND SUSTAINABILITY ISSUES

ISSN 2345-0282 (online) http://jssidoi.org/jesi/

2020 Volume 7 Number 3 (March)

http://doi.org/10.9770/jesi.2020.7.3(73)

Table 3. Ranking of respondents' motivational factors

\begin{tabular}{|c|c|c|c|c|c|c|}
\hline \multicolumn{7}{|c|}{ Please rank accordingly the following factors: } \\
\hline Factor & \multicolumn{6}{|c|}{ Respondents percentage who placed the factor at: } \\
\hline $\begin{array}{l}\text { Employee } \\
\text { Compensation }\end{array}$ & $54 \%$ & $19 \%$ & $12 \%$ & $9 \%$ & $6 \%$ & 0 \\
\hline working conditions & $4 \%$ & $22 \%$ & $26 \%$ & $21 \%$ & $18 \%$ & $9 \%$ \\
\hline $\begin{array}{l}\text { relationships and } \\
\text { communication within } \\
\text { the company }\end{array}$ & $4 \%$ & $24 \%$ & $24 \%$ & $22 \%$ & $16 \%$ & $10 \%$ \\
\hline work/life balance & $3 \%$ & $12 \%$ & $17 \%$ & $26 \%$ & $29 \%$ & $13 \%$ \\
\hline Workplace security & $2 \%$ & $3 \%$ & $3 \%$ & $10 \%$ & $22 \%$ & $60 \%$ \\
\hline
\end{tabular}

\subsection{Comment on the results of open questions to identify missing influential factors}

Respondents have indicated as the strongest motivation to work in their companies different factors related to working conditions, relationships and communication within the company, training and opportunity for new positions and preserved work/life balance. Almost no one mentions Employee Compensation. This is natural because respondents, on the one hand, want to emphasize that they do not only work for money, but on the other they know that their salary is guaranteed with another employer, too. Indeed, the responses also indicate that there are no other relevant factors influencing motivation.

Women are generally saying that what can best demotivate them are relationships and communication within the company, and the men - Employee Compensation and work/life balance. Here are the other factors that, if absent, are a significant obstacle to building/retaining employees engagement.

Respondents sometimes give non-trivial answers (original answers) to the last question, such as: kindergarten or elementary school, different sports tournaments between colleagues in the company and other companies, etc.

\section{Conclusions}

The present study proves the fundamental role of a group of factors for shaping the commitment of the employees in IT companies in Bulgaria. Two hypotheses have been proven: There is a link between Employee Compensation, working conditions, personal development opportunities and the psychological climate, and employee engagement and that Employee Compensation has exhausted the possibilities to be the only factor to guarantee the commitment of the employees in the IT industry. The results obtained show that companies cannot ignore any of the key motivating factors (Employee Compensation, working conditions, relationships and communication in the company, training and opportunity for new positions, and the preserved work/life balance and workplace security) without losing employees and/or productivity/efficiency. Further research is needed to specify each of the factors in subgroups of respondents, as well as to start a study in the efforts of the small and medium IT companies to establish a common model of the engagement of the employees in the IT economy in Bulgaria. 


\section{ENTREPRENEURSHIP AND SUSTAINABILITY ISSUES}

ISSN 2345-0282 (online) http://jssidoi.org/jesi/

2020 Volume 7 Number 3 (March)

http://doi.org/10.9770/jesi.2020.7.3(73)

\section{References}

Audit Advice Associates. (2015). Key Factors for Employee Engagement in the ICT Sector in 2015, Computer World, Retrieved January 13, 2019, https://computerworld.bg/it_liders/2015/10/23/3464164_osnovni_faktori_za_angajiranostta_na_slujitelite_v_ikt/\#!prettyPhoto

Bagyo, Y. (2014). Leadership Style in Improving Performance Through Engagement, IOSR Journal of Business and Management, e-ISSN: 2278-487X, p-ISSN: 2319-7668. Volume 16, Issue 5. Ver. II (May. 2014), PP 40-49, Retrieved June 9, 2019, http://iosrjournals.org/iosrjbm/papers/Vol16-issue5/Version-2/G016524049.pdf

BASSCOM. (2014). Barometer 2014, Annual Report On The State of the Software Sector in Bulgaria, November 2014, Retrieved June 19, 2019, https://www.basscom.org/RapidASPEditor/MyUploadDocs/BASSCOM_Barometer_2014_(ENG).pdf

BASSCOM. (2015). Barometer 2015, Annual Report On The State of the Software Sector in Bulgaria, November 2015, Retrieved June 19, 2019, https://www.basscom.org/RapidASPEditor/MyUploadDocs/BASSCOM_Barometer_2015_ENG.pdf

BASSCOM. (2016). Barometer 2016, Annual Report On The State of the Software Sector in Bulgaria, November 2016, Retrieved June 19, 2019, https://www.basscom.org/RapidASPEditor/MyUploadDocs/BASSCOM_Barometer_2016_ENG.pdf

BASSCOM. (2017). Barometer 2017, Annual Report On The State of the Software Sector in Bulgaria, November 2017, Retrieved June 19, 2019, https://www.basscom.org/RapidASPEditor/MyUploadDocs/BASSCOM_Barometer_2017_ENG.pdf

BASSCOM. (2018a). Barometer 2018, Annual Report On The State of the Software Sector in Bulgaria, November 2018, Retrieved June 19, 2019, https://www.basscom.org/RapidASPEditor/MyUploadDocs/BASSCOM_Barometer_2018_ENG.pdf

BASSCOM. (2018b). Bulgarians Abroad Initiative \& Barometer 2018, Retrieved June 19, 2019, https://www.basscom.org/RapidASPEditor/MyUploadDocs/Basscom_Bulgarians_Abroad_\&_Barometer_2018_BG.pdf

Bernardi, A. 2019. The capability approach and organizational climate as tools to study occupational health and safety. Insights into Regional Development, 1(2), 155-169. https://doi.org/10.9770/ird.2019.1.2(6)

European Communities. (2019). EUROSTAT - Information and communication service statistics - NACE Rev. 2, Brussels: European Communities. Retrieved June 5, 2019, https://ec.europa.eu/eurostat/statistics-explained/index.php?title=Information and communication _service_statistics_-_NACE_Rev._2\#Country_overview

Harter, James K. Schmidt, Frank L., Hayes, Theodore L. (2002). Business-unit-level relationship between employee satisfaction, employee engagement, and business outcomes: A meta-analysis, Journal of Applied Psychology, Vol 87(2), Apr 2002, 268-279

Insights Group (2014). Insights Group Ltd., Retrieved April 3, 2019, https://www.insights.com/resources/employee-engagement-throughthe-lens-of-

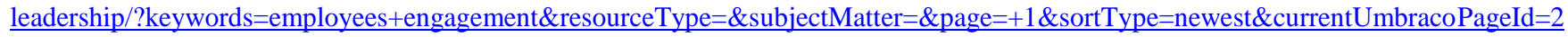
$\underline{891}$

Kenexa. (2013), $2013 \quad$ UNMC Engagement Survey, Kenexa. Retrieved April 9, 2019, https://www.unmc.edu/wwwdocs/2012_UNMC_Engagement_Survey.pdf

Mihova, T., Anguelov, K., Ferdov, A. (2018). Specificity of Training of Employees in High-technological Enterprises, 2018 IX National Conference with International Participation (ELECTRONICA), IEEE https://doi.org/10.1109/ELECTRONICA.2018.8439617

Robinson, D., Perryman, S. Hayday, S. (2002). The Drivers of Employee Engagement, IES Report 387, 2002. ISBN 1851843167 , Retrieved February 12, 2019, https://www.employment-studies.co.uk/system/files/resources/files/408.pdf

Schouten, M.J. 2019. Undoing gender inequalities: insights from the Portuguese perspective. Insights into Regional Development, (2), 8598. https://doi.org/10.9770/ird.2019.1.2(1)

Schuck, M.B., \& Wollard, K.K. (2013). A Historical Perspective of Employee Engagement: An Emerging Definition. Retrieved May 2, 2019, $\quad$ https://pdfs.semanticscholar.org/60d5/557cb81badf82eaa68edb37fd834c57ebdfb.pdf and https://digitalcommons.fiu.edu/cgi/viewcontent.cgi?article=1159\&amp;context=sferc 


\section{ENTREPRENEURSHIP AND SUSTAINABILITY ISSUES}

ISSN 2345-0282 (online) http://jssidoi.org/jesi/

2020 Volume 7 Number 3 (March)

http://doi.org/10.9770/jesi.2020.7.3(73)

Shuck, M.B., \& Wollard, K.K. (2010). Employee Engagement and HRD: A Seminal Review of the Foundations. Human Resource Development Review, 9(1), 89-110, https://doi.org/10.1177/1534484309353560

Stoyanova, Tsvetana. (2018). Organizational effectiveness and employee engagement, paragraphs of the monograph, FAF, Sofia, 2018, pp. 266-279

Stoyanova, Tsvetana, Iliev, Ivaylo (2017). Employee engagement factor for organizational excellence, International Journal of Business and Economic Sciences Applied Research (IJBESAR), 10(1), 23-29.

Thandabhani, M. 2020. Strategic communication for women entrrepreneurs: a case study of India. Insights into Regional Development, 2(1), 480-497. http://doi.org/10.9770/IRD.2020.2.1(7)

Tripathi, J.P, Sharma, S.. (2016). The Key to Improve Performance: Employee Engagement IOSR Journal of Business and Management (IOSR-JBM) e-ISSN: 2278-487X, p-ISSN: 2319-7668. 18(10). Ver. IV (October. 2016), pp. 19-25, Retrieved May 4, 2019, http://www.iosrjournals.org/iosr-jbm/papers/Vol18-issue10/Version-4/C1810041925.pdf

Vance, R J. (2006). Employee Engagement and Commitment -A guide to understanding, measuring and increasing engagement in your organization, 2006 SHRM Foundation, Retrieved February 10, 2019, https://www.shrm.org/hr-today/trends-and-forecasting/specialreports-and-expert-views/documents/employee-engagement-commitment.pdf

Wiley, Jack W. (2010). The impact of effective leadership on employee engagement. Employment Relations, 37(2), 47-52, https://doi.org/10.1002/ert.20297

\section{Acknowledgements}

The authors would like to thank the Research and Development Sector at the Technical University of Sofia, Bulgaria for the financial support.

Kiril ANGUELOV is the Professor of IT Management and Dean of French Faculty of Electrical Engineering at Technical university of Sofia, Bulgaria. Research interests: IT Management; Reengineering; Industrial management and engineering; EU funds management. In these areas, he is recognized as a national expert by consulting both public authorities and private companies.

ORCID ID: $\underline{\text { https://orcid.org/0000-0001-7936-3290 }}$

Tsvetana STOYANOVA is the Assoc. Prof. Dr. of Department of Management, University of National and World economy - Sofia, Bulgaria. Tsvetana has more than 70 publications and in the fields of Strategic Management, Human Resource Management and Leadership.Tsvetana has a broad experience in consulting many public and private businesses.

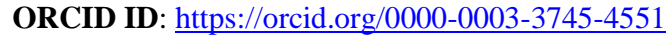

Rima TAMOŠI ŪNIENĖ is the Professor of Financial Engineering Department at Business Management Faculty, Vilnius Gediminas Technical University, Lithuania. Research interests: e-business projects and models, investment evaluation and management, risk management, sustainability.

ORCID ID: $\underline{\text { https://orcid.org/0000-0001-8667-3713 }}$

Copyright (C) 2020 by author(s) and VsI Entrepreneurship and Sustainability Center

This work is licensed under the Creative Commons Attribution International License (CC BY).

http://creativecommons.org/licenses/by/4.0/

(c) (i) Open Access 